\title{
Specifics of Integration Processes Development between Russia and Abkhazia
}

\author{
1, 2,3,4 Timur Z. Mansurov, Andrey V. Ivanov, Andrey G. Bolshakov, Elena A. Tereshina \\ ${ }^{1}$ Kazan Federal University, Institute of Social and Philosophical Sciences and Mass Communications, \\ E-mail: timur-man333@mail.ru,Contact: 89872849616
}

Received: 21st October 2017 Accepted: 16th November 2017, Published: 31st December 2017

\begin{abstract}
Research objective is detecting features and contradictions in integration processes between Russia and Abkhazia. The historical and cultural, social and economic, political, strategic relations of two countries are considered. A number of the contracts promoting development of integration of two states after recognition of independence of Abkhazia by Russia are analyzed. It is emphasized that forming close cooperation and integration becomes possible only after recognition of independence of the former Georgian autonomy and establishment with it diplomatic relations. Special attention is paid to specifics of integration form of Russia and Abkhazia, as well as positive and negative factors in its development. Contradictions of the integration processes connected, in particular, with existence of the competing regional projects developing in the Georgia - the European Union and Russia - Abkhazia - the Eurasian Economic Union formats are analyzed. Economic opportunities of Abkhazia and the prospect of development of the relations with the states of South Caucasus are emphasized. In article it is noted that signing of "The contract between the Russian Federation and the Republic of Abkhazia on alliance and strategic partnership" made active the project of construction of the national state assuming independence and carrying out independent foreign and domestic policy. Despite sufficient asymmetry in the relations of two countries, their further development is mutually advantageous process. Authors come to a conclusion that participation of Abkhazia in integration processes with Russia opens not only new opportunities of economic development, but also promotes the solution of political affairs, including the interethnic conflicts.
\end{abstract}

Keywords: Integration, Russia, Abkhazia, "The Unrecognized State", Interethnic Conflict, Safety, Strategic Partnership.

\section{Introduction}

The problem of development of the relations between "the unrecognized states" and the states having the international recognition draws the increasing attention of both domestic and foreign researchers. Relevance to the matter is given by the political transformations happening on the former Soviet Union within which "the unrecognized states" try to build the integration projects promoting their "survival" and independent development. Their quality and extent of realization in the conditions of lack of full international recognition depends on stability of the state institutes and development of the relations with the regional countries.

Today the works devoted to a research of specifics of integration process between Russia and Abkhazia, slightly. They suffer from lack of the complex analysis of this problem. At the same time, studying of features of integration will help to understand and offer versions of the solution of the existing complex of contradictions and the conflicts in social, economic, political and other spheres affecting Russia and Abkhazia as well as the states of South Caucasus. The proceeding processes demand scientific judgment and the analysis, and the competent prevention of the arising conflicts will promote ensuring stability and safety of the region.

\section{Methods}

Development of the relations of Russia and Abkhazia during the Post-Soviet period was carried out rather not easy. Within the 1990th years Russia gave economic and political support of Georgia and supported territorial integrity of the country [1]. Economic sanctions were inflicted on Abkhazia. Warming in the relations between "unrecognized republic" and Russia happens since the beginning of the 2000th years when Georgia begins to change gradually a vector of the foreign policy, being guided by Euro-Atlantic structures [2]. Russia, including South Caucasus a zone 
of the traditional interests, is not interested in losses of strategic positions, and the mode of economic sanctions weakens. Nevertheless, forming close cooperation and integration of Abkhazia and Russia becomes possible only after recognition of independence of two former Georgian autonomies and establishment with them diplomatic relations.

In article as methodology of a research system and institutional approaches are applied. System approach allowed carrying out the complex analysis of the relations between the Russian Federation and the Republic of Abkhazia in various spheres making an essence of integration processes between the states. Application of an institutional method promoted studying of influence of standard and legal base, as well as the interstate institutes and organizations defining process of integration between Russia and Abkhazia.

\section{Results and Discussion}

Forming integration projects and attempt of their realization in Abkhazia are characterized by own specifics. In 2008 between the Russian Federation and Abkhazia "The treaty of friendship, cooperation and mutual aid between the Russian Federation and the Republic of Abkhazia", promoting development of the relations in various spheres and integration of two states was signed [3]. One of the main tasks of this contract was ensuring military-political safety of Abkhazia, its territorial integrity and sovereignty. Other not less important task supposed carrying out the coordinated foreign policy and ensuring stability in the region. Signing of this document is represented quite natural, considering close historical and cultural, social and economic and political connections of two states.

Closer development of the relations of two countries was promoted by the "Contract between the Russian Federation and the Republic of Abkhazia on alliance and strategic partnership" signed by the parties in 2014. According to provisions of the contract, it consists for achievement of qualitatively new level of regional security, alliance and strategic partnership [4]. Unlike "The treaty of friendship, cooperation and mutual aid between the Russian Federation and the Republic of Abkhazia", the signed document is designed to promote deepening of the relations of two states, formation of the general spaces in various spheres of interaction, as well as to creation of conditions for participation of the Republic of Abkhazia in integration processes in the former Soviet Union.
The text of the contract assumes standardization of the legislation of Abkhazia in tax, budgetary, customs spheres with the relevant standards of Russia and the Customs Union. Unification affects also such important spheres as education and health care, medical standards, promoting increase in living standards of the population of the republic [4]. It is planned to carry out all these tasks due to the Russian financing.

Signing of the contract caused ambiguous understanding in the Abkhazian society [5]. On the one hand, Abkhazians are afraid that its conclusion can cause damage to sovereignty of the country, independence restriction as assumes transformation of the legislative base according to external standards. At the same time the Abkhazian society does not see an alternative to development of close friendship with Russia, and implementation of the contract periodically is a subject of political debates between the power and opposition. On the other hand, the population has an overestimated expectation of various benefits from signing of the contract and first of all material character [6].

Speaking about the relations of strategic partnership between Russia and Abkhazia, it should be noted advantages of their development with "unrecognized republic" for the most Russian Federation. It is absolutely obvious that geopolitical changes on the former Soviet Union and a complication of an international situation increase the importance of Abkhazia as economic and military-political ally. In the conditions of the modern international relations complicated by various factors of conflict, Russia needs allies and development of integration processes which will level the threats and calls of safety existing on perimeter of the Russian borders [1]. Despite evolutionary character in development of the RussianAbkhazian relations, signing of contracts by the parties was the answer to the existing dangers in the region and deepening of the relations of Georgia with EuroAtlantic structures, in particular, on signing of "The agreement on association of the EU with Georgia". At the same time Abkhazian support allows Russia to keep positions in South Caucasus and to provide the internal interests in the North Caucasian region.

At the same time, formation of integration processes promotes emergence of regional contradictions. They are connected with existence of the competing projects developing in the Georgia - the European Union and Russia - Abkhazia - the Eurasian Economic Union 
formats. The last format is a little conditional as Abkhazia - not the member of the Eurasian Economic Union, and prospects of its accession to this organization are not clear yet. The existing projects create tension, confrontation and are an incentive for deepening of integration with the partners. At the same time both Russia and Georgia support normalization of the relations of two countries, but this process is interfered by not resolved ethno-political conflicts [7].

It is possible to note that deepening of Euro-Atlantic integration of Georgia as a counterbalance to the Russian influence promotes reduction of opportunities for reintegration of "the unrecognized state". As the domestic researcher S. Markedonov fairly noticed, "Strengthening Euro-Atlantic vector of Georgia is simultaneous strengthening of Abkhazian "egoism" in which the Russian factor is extremely important, though is not absolute" [8]. Implementation of economic and political processes in Abkhazia is not considered in the context of the general Georgian policy and the territorial conflicts any more as it was earlier, and Abkhazia actually (but not legally) became a part of the North Caucasian format of the Russian policy. In this context also regional identity of "partially recognized republic" is formed.

The relations between Russia and Abkhazia after signing of the contract on alliance and strategic partnership are characterized by a specific form of integration. They represent a certain symbiosis of the relations proceeding within the Union State and the regional organization. However today integration processes between Russia and Abkhazia do not assume creation of supranational bodies as, for example, it exists in the Union State of Russia and Belarus. On the other hand, provisions of the contract speak about formation of the general spaces in the field of defense and safety, as well as social, economic, cultural, spiritual and humanitarian spheres that brings closer the relations of two countries to the relations of the states within the European Union. On some indicators, for example, in military-political and partly in economic spheres of the relation of Abkhazia and Russia is much closer, than within the EU, but at the same time Abkhazia did not overcome such step of integration as the Customs union, and between two countries there is only a free trade zone.

The features of integration processes considered above concern only Russia and Abkhazia, at the same time, integration of "unrecognized republic" into any structures at the former Soviet Union or beyond its limits remains still uncertain. Efforts Russia in this direction can be insignificant as the organizations which include the countries of the former Soviet Union (the CIS, the CSTO, the Eurasian Economic Union, $\mathrm{SCO}$, etc.) make internationally recognized states, and the policy of Russia will encounter resistance of other members of the organizations. The crossed difficulties in this question were experienced by Armenia at entry into the Eurasian Economic Union, considering a factor of its close relations with the Nagorno-Karabakh Republic. The available contradictions managed to be resolved as integration of Armenia into the supranational organization was carried out within internationally recognized borders of the independent state, disregarding the territory of Nagorno-Karabakh and seven areas which are under control of Armenia.

Perhaps, development of the relations of Abkhazia with Russia and other countries of the region would be promoted by further normalization of the RussianGeorgian relations and participation of Georgia in this or that form in integration processes in the former Soviet Union. However today there are no visible factors which would lead to change of a vector of EuroAtlantic orientation of foreign policy of Georgia. The Georgian leaders apprehended signing of the contract on alliance and strategic partnership as the next step on the way to annexation of "unrecognized territories". At the same time, in the Georgian society there are serious fears that process of integration between Abkhazia and Russia, strengthening of statehood, development of international relations of "unrecognized republic" more and more levels chances on return of the former autonomies.

Before signing of the contract on alliance and strategic partnership as the domestic researcher N. Mendkovich truly noticed, "the current status quo to some extent suited Tbilisi as Abkhazia was not perceived by many in the region as the successful state project that allowed to weaken internal political tension on a problem of the lost territories several and to keep hope to achieve once in the future their return" [9]. The new contract brings the relations of the parties to qualitatively new level, has a prosy economic basis, the considerable prospects of realization and is not aimed at political integration of the states.

Today priorities for Abkhazia are increase in number of the states recognizing its independence, deepening of the relations with Russia, in particular, development of 
cooperation with the North Caucasian republics, as well as continuation of negotiation process with Georgia in the Geneva format and within the Mechanism on prevention and response to incidents in border areas of the Republic of Abkhazia and Georgia. After election as the president of Abkhazia R. Khadjimba in the republic was initiated the project of creation of autonomous economy due to development of tourist and agrarian sectors, and not just by means of trenches from Russia [10]. At the same time, it is rather obvious that creation of own full-fledged economy, considering for many years its stay in crisis state, as well as development, the surpassing in many parameters, alternative spheres in the Crimea and in Krasnodar Krai, is represented problematic even in the long term. Today the budget of "unrecognized republic" for $70 \%$ is provided with the Russian financing that allows adopting various plans, programs, to realize projects of social and economic development.

Certainly, the economic capacity of Abkhazia is considerable, and its increase will be promoted by integration between the Russian Federation and Abkhazia. Despite existence of several competing integration projects in the region, today they seem an alternative to power version of the decision of the interethnic conflicts and safety.

Development of integration of two countries is also promoted by character of the existing political and economic relations between the states of South Caucasus. This state was truly noticed by the Armenian researcher A. Iskandaryan who told that in the region "on the one hand, need to consider dependence on Russia in economic, military and political spheres in different configurations, and on the other hand unwillingness to spoil the relations with the USA and the EU, led to such policy when the countries of South Caucasus keep a configuration of internal relationship, extremely carefully behaving with large external players and trying to keep balance within available for each of the countries of opportunities" [11]. Maintenance of balance of the political relations between the countries is possible only at the accounting of interests of the partners and realization on these fundamentals of mutually advantageous policy.

\section{Summary}

Recognition of independence of Abkhazia gave a significant impulse to development of processes of integration between two countries. Formation of the relations of alliance and strategic partnership is the mutually advantageous process promoting ensuring military-political safety and stability in the South Caucasian region. In the conditions of political and economic isolation of Abkhazia leveling of threat to security from Georgia is an important factor of social and economic development of the republic. Abkhazia is on crossing of important transport and communication ways, and the integration processes proceeding in the Eurasian region, including advanced by Russia can promote development of the Georgian-Abkhazian relations in the context of logic not of confrontation, and mutually beneficial cooperation. Such situation opens absolutely new prospects and economic revival of the region and realization of interests of big and small players in a regional context, including the territorial conflicts.

\section{Conclusion}

Signing of the contract on alliance and strategic partnership gave an additional impulse of activation of request of the Abkhazian society for implementation of the project of construction of the national state assuming independence and independence in domestic and foreign policy. Despite existing concern and the fears connected, on the one hand, with aspiration to independent development, and, on the other hand, creation of the asymmetric relations between the countries are not taken by Russia any actions directed to restriction of sovereignty of Abkhazia. The signed contract, considering rough and long discussions concerning its contents, acted as result of compromises between the parties, and noted condition of the Abkhazian society is explained rather by difficulties of social and economic development and crisis processes the former Soviet Union, than contents of the contract.

\section{Acknowledgement}

The work is performed according to the Russian Government Program of Competitive Growth of Kazan Federal University.

\section{References}

[1] Mansurov T. Z. Russian-Georgian dialogue on normalization of relations: limits and spheres of interaction//Bulletin of Voronezh State University. Series: History. Political science. Sociology. - 2016. - No. 3. - Page 30-36.

[2] Lynch D. Russian peacekeeping strategies in the CIS: case of Moldova, Georgia and Tadjikistan. - London: Macmillan Press. - 1999. - P. 132135.

[3] Treaty of friendship, cooperation and mutual aid between the Russian Federation and Republic of Abkhazia.

URL: 
http://www.conventions.ru/view base.php?

$\mathrm{id}=8422$, free. It is checked 2.07.2017.

[4] Contract between the Russian Federation and Republic of Abkhazia on alliance and strategic partnership.

URL: http://www.kremlin.ru/supplement/4783, free. It is checked 2.07.2017.

[5] Abkhazia's unequal partnership with Russia. URL: http://caucasustimes.com/en/abkhaziasunequal-partnership-with-russia/, free. It is checked 4.07.2017.

[6] "An external contour of defense" of Russia and Abkhazia: problems and prospects. URL: http://www.kavkazoved.info/news/2014/10/04/v neshniy-kontur-oborony-rossii-i-abhazii-

problemy-i-perspektivy.html, free. It is checked 4.07.2017.

[7] Timur Z. Mansurov, Elena A. Tereshina, Andrey V. Ivanov, Natalia A. Shibanova. The Process of Normalization of Russian-Georgian Relations: Limits and Spheres of Interaction between States//Journal of Organizational Culture, Communications and Conflict. Volume 20. Special Issue 2. - 2016. - P. 114119.

[8] Markedonov S. Lessons of Abkhazia. URL: http://globalaffairs.ru/global-processes/UrokiAbkhazii-16685, free. It is checked 5.07.2017.

[9] Mendkovich N. Reaction of Georgia to the Russian-Abkhazian contract on alliance. URL: http://www.kavkazoved.info/news/2014/10/27/r eakcia-gruzii-na-rossijsko-abhazskij-dogovor-osouznichestve.html, free. It is checked 5.07.2017.

[10] Petrosyan D. De facto the states of South Caucasus in 2014//Caucasus 2014. CI Yearbook/Ed. A. Iskandaryan. - Yerevan: Caucasus Institute, 2016. - P. 52-70.

[11] Iskandaryan A. Post-Crimean Russia and South Caucasus//Caucasus 2014. CI Yearbook/Ed. A. Iskandaryan. - Yerevan: Caucasus Institute, 2016. - P. 93-99. 